\section{Disease Reaction among Selected Cucurbitaceae to an Acremonium cucurbitacearum Isolate from Texas}

\author{
B.D. Bruton ${ }^{1}$ \\ U.S. Department of Agriculture, Agricultural Research Service, South Central \\ Agricultural Research Laboratory, Lane, OK 74555
}

T.W. Popham

U.S. Department of Agriculture, Agricultural Research Service, Southern Plains Area, Stillwater, OK 74074

J. García-Jiménez and J. Armengol

Unidad de Patología Vegetal, Departamento de Produccion Vegetal, Universidad Politécnica, Camino de Vera s/n, 46020 Valencia, Spain

\section{M.E. Miller \\ Texas Agricultural Experiment Station, Texas A\&MUniversity System, Weslaco, TX 78596}

Additional index words. vine decline, root rot, disease severity index, soilborne disease, cucurbits, host-plant resistance, Citrullus sp., Cucumis sp., Cucurbita sp., Lagenaria sp., Luffa sp.

\begin{abstract}
Thirty-seven species within Cucurbitaceae representing the genera Citrullus, Cucumis, Cucurbita, Lagenaria, and Luffa were evaluated for disease reaction to an Acremonium cucurbitacearum A. Alfaro-Garcia, W. Gams, and Garcia-Jimenez, isolate (TX 941022) from the Lower Rio Grande Valley of Texas. After 28 days in the greenhouse, seedling disease ratings were made on the hypocotyl, stem-root junction, primary root, and secondary roots. An additional disease measure was derived by averaging the four root disease ratings to establish a disease severity index (DSI). Vine and root dry weight were poor measures of plant damage caused by A. cucurbitacearum. According to the DSI, all species within Cucurbita, Lagenaria, Luffa, and three Cucumis sativus L. cultigens were rated as highly resistant to A. cucurbitacearum. Cucumis melo L. and Citrullus lanatus (Thunb.) Matsum. \& Nakai cultigens were the only cucurbits receiving DSI ratings of moderately resistant to susceptible.
\end{abstract}

Cucurbits are commercially important in many parts of the world. The continuous and intensive cultivation of these crops, along with changing cultural practices, have resulted in the increased incidence and severity of a group of soilborne diseases known as vine declines (Bruton et al., 1998). Vine decline is a general term applied to a group of soilborne diseases with similar symptoms, but with different causal agents (Bruton, 1996b; Bruton et al., 1988; Miller et al., 1995). Symptoms include yellowing and death of the crown leaves and death of the vine as the fruit approach matu-

\footnotetext{
Received for publication 16 Mar. 1999. Accepted for publication 5 Nov. 1999. Mention of a trademark, proprietary product, or vendor does not constitute a guarantee or warranty of the product by the U.S. Dept. of Agriculture and does not imply its approval to the exclusion of other products of vendors that may also be suitable. The cost of publishing this paper was defrayed in part by the payment of page charges. Under postal regulations, this paper therefore must be hereby marked advertisement solely to indicate this fact.

${ }^{1}$ To whom reprint requests should be addressed. E-mail address: bbruton-usda@lane-ag.org
}

rity. In some cases, the effects of the disease occur more suddenly, causing wilting or collapse of the vine. Vine decline of melons may be provoked by vascular wilts, crown rots, or root rots (Bruton, 1998). Fruit from affected plants are more likely to sunburn, have lower sugar content, and abscise from the peduncle prior to normal ripening. Because cucurbit resources, including labor, fertilizer, and pesticides, vine decline diseases account for substantial economic losses.

An emerging disease of melon, called Acremonium collapse, having symptoms consistent with vine decline was described in Spain (Garcia-Jimenezet al., 1994b). Recently, the fungus causing Acremonium collapse was identified as Acremonium cucurbitacearum A. Alfaro-Garcia, W. Gams, \& Garcia-Jimenez (Alfaro-Garcia et al., 1996). In Spain, the disease is referred to as melon collapse (colapso) or sudden death (muerte súbita) due to the rapid death of affected plants as the fruit approach maturity. Symptoms are described as a nonvascular plant wilt or collapse just prior to harvest (Garcia-Jimenez et al., 1994b). Other characteristics may include a corky and production often involves high inputs of somewhat distorted root system. Affected roots generally are not water-soaked or macerated but exhibit a rough and corky appearance. In California, A. cucurbitacearum was first described as a hypocotyl rot of melon, but was not associated with vine decline of mature plants (Gubler, 1982). More recently, the fungus has been associated with vine decline of melon in the upper San Joaquin Valley and the Sacramento Valley (Bruton et al., 1995; Gwynne et al., 1997) causing serious economic losses in some years. In Texas, $A$. cucurbitacearum has been isolated from melon and watermelon roots in the Lower Rio Grande Valley (LRGV) (Bruton et al., 1996b). However, the fungus does not appear to cause a detectable level of disease in the LRGV. Whether this difference is due to host specificity between isolates from Spain and Texas or environmental differences is not known. Armengol et al. (1998) showed a wide range of susceptibility within Cucurbitaceae to $A$. cucurbitacearum isolates from Spain, with Citrullus lanatus and Cucumis melo being most susceptible.

The purpose of this study was to determine the disease reactions of representative members of the Cucurbitaceae to an A. cucurbitacearum from Texas. A portion of this study has been published in abstract form (Bruton et al., 1996b).

\section{Materials and Methods}

Inoculation and disease assessment. A reference isolate of $A$. cucurbitacerum from Texas (TX 941022) was selected to determine the disease reactions of a wide range of cucurbit species. Thirty-seven cucurbits were tested comprising five genera and 11 different species (Table 1). The fungal isolate, stored in glass vials of sterilized potting soil (TerraLite; Scotts-Sierra Hort. Products Co., Marysville, Ohio), was transferred to potato dextrose agar (PDA), allowed to grow for $7 \mathrm{~d}$, and subsequently introduced to a growth medium consisting of coarse sand $(0.45-$ $0.55-\mathrm{mm}$ swimming pool filter sand; Wedron Silica Co., Wedron, Ill.), and ground oat hulls (Avena sativa L., The Quaker Oats Co., Chicago). Five hundred milliters of sand was mixed with $45 \mathrm{~g}$ oat hulls in a 1-L flask. One hundred milliters of water was added to the mix, which was then autoclaved three times for $1 \mathrm{~h}$ at 2 -d intervals. Once the fungal colonies reached $\approx 5 \mathrm{~cm}$ diameter, the contents were shaken vigorously to thoroughly mix them for more even distribution throughout the medium. After $28 \mathrm{~d}$, the contents were thoroughly mixed again and a subsample ( $1 \mathrm{~g}$ ) was removed to determine colony-forming units (cfu) per gram of inoculum. The subsample was added to $99 \mathrm{~mL}$ of sterile $2 \%$ hydroxy-ethyl cellulose (Aldrich, Milwaukee) along with a stir bar, and placed on a stirplate for $1 \mathrm{~min}$. Subsequent dilutions to the power of $10^{5}$ were required to obtain accurate colony counts on the PDA plates. Five plates/dilution were incubated for $3 \mathrm{~d}$ at room temperature to determine cfu per gram of inoculum. During the 3-d incubation period, the original inocu- 


\begin{tabular}{|c|c|c|c|c|c|c|c|}
\hline \multirow[b]{2}{*}{ Cultigen\# } & \multirow[b]{2}{*}{ Scientific name/Authority } & \multirow[b]{2}{*}{ Cultigen/Common name } & \multirow[b]{2}{*}{$\mathrm{DSI}^{\mathrm{y}}$} & \multicolumn{4}{|c|}{ Disease rating $^{\mathrm{z}}$} \\
\hline & & & & Hypocotyl & $\begin{array}{l}\text { Stem-root } \\
\text { junction }\end{array}$ & $\begin{array}{c}\text { Primary } \\
\text { root }\end{array}$ & $\begin{array}{l}\text { Secondary } \\
\text { roots }\end{array}$ \\
\hline 1 & $\begin{array}{l}\text { Cucurbita moschata (Duchesne) } \\
\text { Duchesne ex Poir. }\end{array}$ & Butternut Waltham, winter squash & $1.2 \pm 0.03^{\mathrm{x}}$ & $1.3 \pm 0.07$ & $1.4 \pm 0.08$ & $1.0 \pm 0.00$ & $1.0 \pm 0.00$ \\
\hline 2 & Cucurbita maxima Duchesne & Golden Delicious, pumpkin & $1.3 \pm 0.06$ & $1.1 \pm 0.05$ & $1.8 \pm 0.13$ & $1.2 \pm 0.07$ & $1.1 \pm 0.05$ \\
\hline 3 & Cucurbita moschata & Lumina, pumpkin & $1.3 \pm 0.05$ & $1.2 \pm 0.06$ & $1.7 \pm 0.11$ & $1.1 \pm 0.05$ & $1.1 \pm 0.05$ \\
\hline 4 & Cucurbita maxima & Turks Turban, gourd & $1.3 \pm 0.05$ & $1.3 \pm 0.07$ & $1.9 \pm 0.14$ & $1.1 \pm 0.05$ & $1.0 \pm 0.00$ \\
\hline 5 & Cисиrbita pepo $\mathrm{L}$. & Hawden, pumpkin & $1.3 \pm 0.09$ & $1.3 \pm 0.08$ & $1.5 \pm 0.12$ & $1.2 \pm 0.08$ & $1.3 \pm 0.10$ \\
\hline 8 & Сисurbita реро & Connecticut Field, pumpkin & $1.4 \pm 0.06$ & $1.5 \pm 0.09$ & $1.7 \pm 0.12$ & $1.2 \pm 0.06$ & $1.1 \pm 0.05$ \\
\hline 9 & Luffa aegyptiaca Mill. & Luffa (13204), gourd & $1.4 \pm 0.09$ & $1.0 \pm 0.05$ & $1.4 \pm 0.11$ & $1.5 \pm 0.13$ & $1.5 \pm 0.13$ \\
\hline 10 & Lagenaria siceraria & Calabash, gourd & $1.4 \pm 0.09$ & $1.2 \pm 0.09$ & $1.9 \pm 0.16$ & $1.2 \pm 0.13$ & $1.1 \pm 0.10$ \\
\hline 11 & Cucurbita argyrosperma $\mathrm{C}$. Huber & Cushaw Green Striped, pumpkin & $1.4 \pm 0.08$ & $1.4 \pm 0.07$ & $1.5 \pm 0.09$ & $1.4 \pm 0.10$ & $1.3 \pm 0.09$ \\
\hline 12 & Cucumis sativus $\mathrm{L}$. & Poinsett 76 , cucumber & $1.5 \pm 0.12$ & $1.2 \pm 0.09$ & $1.9 \pm 0.22$ & $1.4 \pm 0.12$ & $1.3 \pm 0.10$ \\
\hline 13 & Cucurbita pepo & e Queen Acorn, winter squash & $1.5 \pm 0.08$ & $1.5 \pm 0.09$ & $1.7 \pm 0.09$ & $1.4 \pm 0.11$ & $1.5 \pm 0.11$ \\
\hline 14 & Cucurbita moschata & Dickinson, pumpkin & $1.5 \pm 0.14$ & $1.7 \pm 0.13$ & $1.9 \pm 0.15$ & $1.3 \pm 0.15$ & $1.3 \pm 0.15$ \\
\hline 19 & Cucurbita pepo & Grey Zucchini, summer squash & $1.7 \pm 0.10$ & $1.8 \pm 0.11$ & $1.9 \pm 0.12$ & $1.6 \pm 0.10$ & $1.6 \pm 0.10$ \\
\hline 20 & Cucurbita foetidissima Kunth. & Buffalo Gourd, gourd & $1.7 \pm 0.10$ & $1.4 \pm 0.10$ & $1.8 \pm 0.15$ & $1.9 \pm 0.14$ & $1.8 \pm 0.13$ \\
\hline 21 & Cucumis sativus & Bush Pickle, cucumber & $1.8 \pm 0.16$ & $1.6 \pm 0.18$ & $2.1 \pm 0.24$ & $1.5 \pm 0.15$ & $1.8 \pm 0.18$ \\
\hline 22 & Cuсumis sativus & Bush Crop, cucumber & $1.9 \pm 0.19$ & $1.2 \pm 0.12$ & $2.3 \pm 0.26$ & $2.1 \pm 0.23$ & $2.0 \pm 0.23$ \\
\hline 23 & $\begin{array}{l}\text { Citrullus lanatus (Thunb.) Matsum. } \\
\text { \& Nakai }\end{array}$ & Arriba, watermelon & $2.3 \pm 0.24$ & $2.3 \pm 0.25$ & $2.5 \pm 0.26$ & $2.3 \pm 0.24$ & $2.3 \pm 0.24$ \\
\hline 24 & Cucumis melo inodorus Jacq. & & 3 & 26 & $2.7 \pm 0.26$ & $2.3 \pm 0.22$ & $2.3 \pm 0.21$ \\
\hline 25 & Cucumis melo cantalupensis Naud. & WXC951, melon & $2.6 \pm 0.23$ & $2.7 \pm 0.24$ & $2.7 \pm 0.25$ & $2.5 \pm 0.24$ & $2.4 \pm 0.24$ \\
\hline 26 & Cucumis melo inodorus & Magic To Dew, melon & $2.7 \pm 0.25$ & $2.9 \pm 0.27$ & $2.8 \pm 0.27$ & $2.5 \pm 0.25$ & $2.5 \pm 0.25$ \\
\hline 27 & Cucumis melo inodorus & Green Flesh, melon & $2.8 \pm 0.27$ & $3.1 \pm 0.33$ & $3.1 \pm 0.32$ & $2.5 \pm 0.25$ & $2.6 \pm 0.24$ \\
\hline 28 & Cucumis melo cantalupensis & Marco Polo, melon & $2.9 \pm 0.26$ & $2.9 \pm 0.27$ & $3.0 \pm 0.28$ & $2.8 \pm 0.27$ & $2.8 \pm 0.26$ \\
\hline 29 & Cucumis melo inodorus & Morning Ice, melon & $2.9 \pm 0.25$ & $2.7 \pm 0.26$ & $3.1 \pm 0.26$ & $3.0 \pm 0.25$ & $2.9 \pm 0.25$ \\
\hline 30 & Cucumis melo flexuosus (L.) Naud. & Banana, melon & $2.9 \pm 0.27$ & $2.7 \pm 0.28$ & $3.0 \pm 0.28$ & $3.0 \pm 0.28$ & $2.9 \pm 0.28$ \\
\hline 31 & Cucumis melo chito (E. Morr.) Naud. & Vine Peach, melon & $3.0 \pm 0.26$ & $2.6 \pm 0.27$ & $3.0 \pm 0.27$ & $3.1 \pm 0.27$ & $3.1 \pm 0.26$ \\
\hline
\end{tabular}

${ }^{2}$ Rated 1 to 5 , where 1 is healthy and 5 is severely diseased. These ratings can be converted to an equivalent rating scale for GRIN by multiplying the above averages by 2 and subtracting 1 .

${ }^{y}$ Disease severity index (DSI) is the average of four individual root ratings.

${ }^{\mathrm{x}}$ Mean \pm one standard error $(\mathrm{n}=10)$.

lum was maintained at $23^{\circ} \mathrm{C}$ in the laboratory.

Five pots were infested with $10,000 \mathrm{cfu}$ per gram of soil, based on previous studies (Bruton et al., 1996a, 1996b). About 7-10 seeds, representing each test cucurbit species, were placed on the soil and an additional $4 \mathrm{~cm}$ of infested soil was added to fill the pot (14.5 $\times 11.0 \mathrm{~cm})$. An equal number of pots without inoculum were planted with each cucurbit species to serve as controls. The pots were transferred to the greenhouse and arranged in a randomized complete-block design. Following seedling emergence, plants were thinned to five per pot. Each pot was fertilized weekly with 0.1\% Peters 20:20:20 (Grace-Sierra Hort. Products, Milpitas, Calif.). Soil temperature in the pots was recorded every minute, averaged for the hour for each 24-h period, using a CR 10 data logger (Campbell Scientific, Logan, Utah). Mean temperature in the greenhouse was $18{ }^{\circ} \mathrm{C}$ at night and $26^{\circ} \mathrm{C}$ during the day.

After $28 \mathrm{~d}$, the plants were removed from the pots and washed gently to remove soil from the roots. Root systems were immediately rated for disease. The disease rating scale for the hypocotyl (RH) was: 1 = healthy with no lesions or discoloration; 2 = slight discoloration; 3 = moderate discoloration and/or with lesions; $4=$ moderate maceration; and $5=$ severe maceration. The scale for the stem-root junction (RSR) was: $1=$ healthy with nolesion or discoloration; $2=$ slight discoloration; $3=$ moderate discoloration but firm: $4=$ moderate discoloration with loss of firmness; $5=$ severe discoloration and macerated. That for the primary $\operatorname{root}(\mathrm{R} 1 \mathrm{R})$ was: $1=$ healthy with no lesions; $2=1 \%$ to $25 \%$ with slight discoloration; $3=>25 \%$ slightly discolored or with lesions; $4=$ moderate discoloration and/or slight maceration; $5=$ severe discoloration and/or macerated. The scale for the secondary roots $(\mathrm{R} 2 \mathrm{R})$ was: 1 = healthy with no lesion or discoloration; 2 = slight discoloration; 3 = slight discoloration with up to $25 \%$ root mass reduction; $4=$ moderate discoloration with up to $50 \%$ root mass reduction; $5=$ severe discoloration with $>50 \%$ root mass reduction. Isolations were made from plants from representative treatments to verify the presence of the inoculated fungus. Stems and leaves (vine) and roots were subsequently dried to constant weight.

Experimental design. The percentage of reduction of vine dry weight (VDW) and root dry weight (RDW) of inoculated plants was computed relative to controls in each study. PROC GLM, version 6.12 (SAS Inst., Cary, N.C.) was used to perform analysis of variance (ANOVA) $(P \leq 0.05)$ to determine the significance of differences among species for each variable (RH, RSR, R1R, R2R, VDW, RDW) and the average of the root ratings (DSI). Standard errors of the means of RH, RSR, R1R, R2R, and DSI for each host were computed. The mean DSI was constructed to determine the overall susceptibility of the test cultigens (Fig. 1). Species receiving a DSI of $<2.0$ were considered highly resistant, 2.0 to 2.9 moderately resistant, 3.0 to 3.9 susceptible, and 4.0 or above highly susceptible. The correlations of VDW and RDW with HR, RSR, $\mathrm{R} 1 \mathrm{R}$, and $\mathrm{R} 2 \mathrm{R}$ were computed for the combined data and a $t$ test was used to test the null hypothesis of $r=0$ with $P \leq 0.05$.

\section{Results}

Symptoms ranged from a few root lesions or slight root discoloration on the most resistant cucurbits to moderately or severely decayed hypocotyl, primary root, and/or secondary roots of the most susceptible ones (Table 1). 


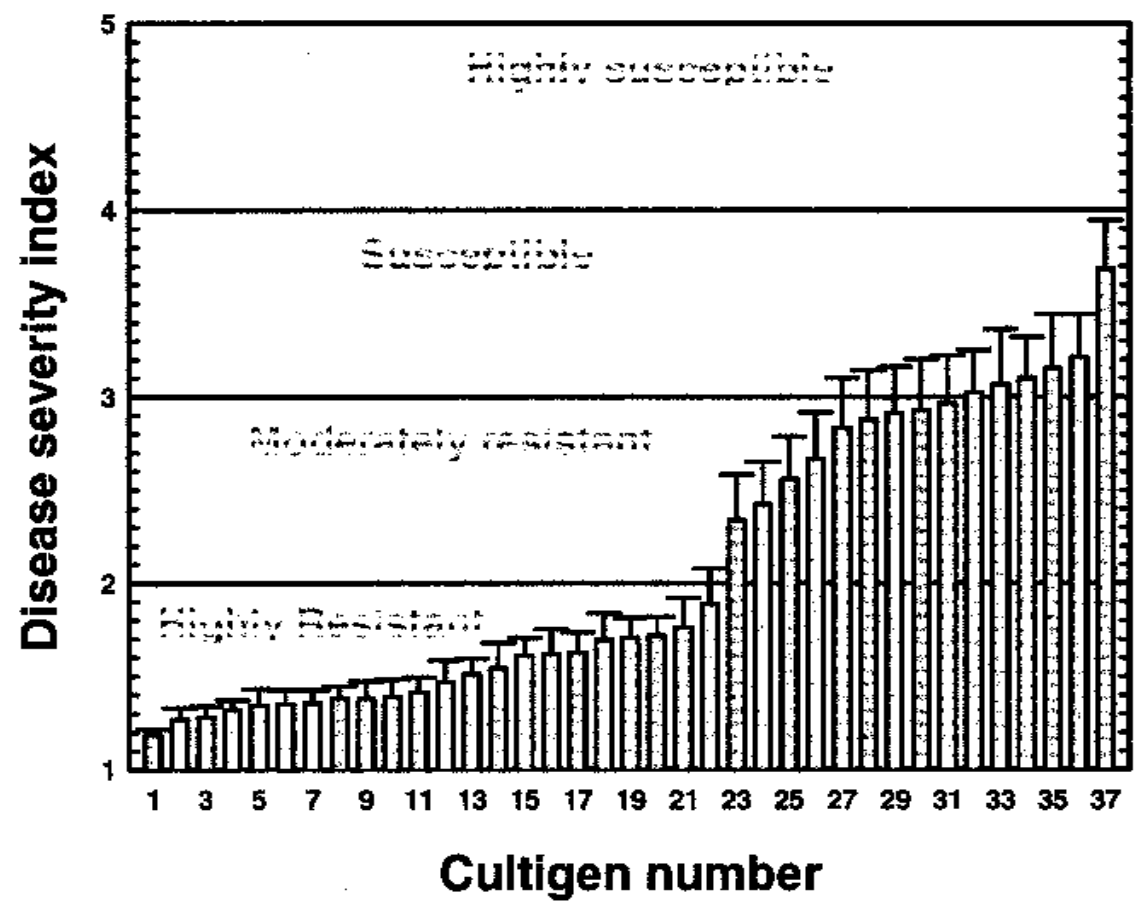

Fig. 1. Disease severity index (DSI) of cucurbits (Table 1) inoculated with an Acremonium cucurbitacearum (TX 941022) isolate from the Lower Rio Grande Valley of Texas. Values are averages over two studies of four root disease ratings (hypocotyl, root-stem junction, primary root, and secondary roots). Cultigens receiving a DSI of 1.0 to 1.9 were considered highly resistant; 2.0 to 2.9 were considered moderately resistant; 3.0 to 3.9 were susceptible; and 4.0 or above were highly susceptible. Vertical bars are one standard error of the mean $(\mathrm{n}=10)$.

Table 2. Correlation coefficients $(r)$ between vine or root dry weight and individual root disease ratings of cucurbit cultigens inoculated with Acremonium cucurbitacearum (TX 941022). None are significantly different from zero at $P<0.05$.

\begin{tabular}{lccccr}
\hline \hline & \multicolumn{2}{c}{ Highly resistant $^{\mathrm{z}}$} & & \multicolumn{2}{c}{ Moderately resistant $^{\mathrm{y}}$ and susceptible $^{\mathrm{x}}$} \\
\cline { 2 - 3 } & Vine dry wt & Root dry wt & & Vine dry wt & Root dry wt \\
\hline Hypocotyl & $0.04\left(0.57^{\mathrm{w}}\right.$ & $-0.14(0.07)$ & & $0.14(0.10)$ & $-0.08(0.35)$ \\
Stem-root junction & $0.07(0.36)$ & $-0.07(0.37)$ & & $0.17(0.05)$ & $-0.02(0.76)$ \\
Primary root & $0.05(0.54)$ & $0.05(0.54)$ & & $0.15(0.08)$ & $0.01(0.91)$ \\
Secondary roots & $0.05(0.54)$ & $0.04(0.64)$ & & $0.15(0.08)$ & $0.01(0.89)$ \\
\hline
\end{tabular}

${ }^{2}$ DSI of 1.0 to 1.9 .

'DSI of 2.0 to 2.9 .

xDSI of 3.0 to 3.9 .

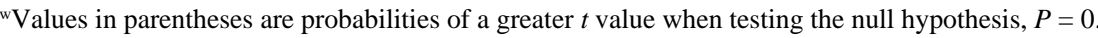

Acremonium cucurbitacearum was isolated from lesions of all cucurbit species tested to confirm the presence of the fungus. Disease ratings were generally higher at the stem-root junction than at the hypocotyl, primary root, or secondary roots. Within the species receiving a DSI <2.0 (highly resistant), there was no correlation between root damage ratings and vine or root dry weight (Table 2 ). Within those receiving a DSI $>2.0$ (moderately resistant to susceptible) only the disease rating at the stem-root junction was correlated with VDW. ANOVA demonstrated that cucurbit species differed significantly $(P \leq 0.05)$ in disease reaction. The means comparison demonstrated a continuum from highly resistant to susceptible (Fig. 1). Twenty-two of the 37 cucurbits tested were highly resistant, with the top four being Cucurbita moschata (Duchesne) Duchesne ex Poir. and Cucurbita maxima
Duchesne cultigens. In fact, all Cucurbita, Luffa, and Lagenaria sp. were in the highly resistant group. Of the Cucumis sp., only $C$. sativus L. cultigens were rated as highly resistant. The only cucurbits not included in the highly resistant group were Citrullus lanatas (Thunb.) Matsum. \& Nakai and Cucumis melo, which were rated as moderately resistant and susceptible (Table 1, Fig. 1). No cucurbits were rated as highly susceptible under the conditions of this study.

\section{Discussion}

This study clearly distinguished commercial cultigens of Citrullus lanatus and Cucumis melo from the other cucurbit species tested as the most susceptible to $A$. cucurbitacearum. Armengol et al. (1998) reported similar results using two Spanish isolates of $A$. cucurbitacearum. They noted that watermelon and muskmelon were generally the most susceptible with Cucurbita maxima, Luffa acutangula, and L. aegyptiaca being most resistant. Gubler (1982) reported a similar disease reaction in Cucumis melo cultigens to A. cucurbitacearum from California, with disease in Citrullus lanatus cultigens and Cucurbita sp. rated as intermediate and light, respectively. Note that $C$. lanatus in Spain is not severely affected by Acremonium collapse (Garcia-Jimenez, personal observations). However, $C$. lanatus in Spain is often grafted onto C. maxima 'Brava', 'Shintoza', or 'RS-841', which may explain the apparent resistance.

Why A. cucurbitacearum causes little or no detectable damage to melons in the LRGV of Texas is not clear because the isolate appears to be similar in host range to the Spanish isolates (Armengol et al., 1998). Based on morphology (Alfaro-Garcia et al., 1996) and vegetative compatibility groupings, California and Texas isolates were determined to be morphologically and genetically similar to Spanish isolates (Abad et al., 1997; Vincente et al., 1996). Nevertheless, environmental conditions may be the primary reason, since temperatures during the later part of the melon growing season in the LRGV are higher than the optimum temperature for growth of the fungus (Armengol, 1997; Bruton et al., 1999). Many of the vine declines in melons are directly associated with environmental conditions, especially temperature (Bruton, 1996a, 1998; Bruton et al., 1999). Gubler (1982) noted that seedling disease, caused by $A$. cucurbitacearum, was considerably reduced at temperatures below $17^{\circ} \mathrm{C}$ and above $27^{\circ} \mathrm{C}$ with an optimum at $24^{\circ} \mathrm{C}$, which are similar to greenhouse temperatures in the present study. Growing conditions such as temperature can have a large impact on seedling emergence, plant growth, and disease response of cucurbits to soilborne pathogens.

We showed that vine and root dry weight were poor measures of plant damage caused by $A$. cucurbitacearum. Similar results have been observed in muskmelon plants inoculated with $M$. cannonballus Pollack \& Uecker (unpublished data). Mertely et al. (1993) demonstrated a significant reduction in root dry weight in only three of 12 cucurbit species inoculated with $M$. cannonballus. Consequently, Mertely et al. (1993) suggested vine length as a convenient nondestructive technique to evaluate plant damage caused by $M$. cannonballus.

In recent years, the necessity for an integrated approach to vine decline management has become apparent. Fumigation has been partially effective in controlling some fungal pathogens causing melon vine decline (Hartz et al., 1987; Miller, 1990), but it is a costly procedure (about $\$ 625 / \mathrm{ha}$ ). Since other agricultural crops and weeds common to melon production fields in Spain and California are not hosts of the fungus (Armengol et al., 1998; Gubler, 1982), crop rotation may be an effective management strategy. Because $A$. cucurbitacearum produces chlamydospores 
(Armengol, 1997; Cluck et al., 1997; Gubler, 1996), longer rotations similar to those for Fusarium wilt (Hopkins and Elmstrom, 1984) may be necessary. Use of Cucurbita maxima $\mathrm{x}$ C. moschata hybrids as rootstocks, has shown potential for control of Acremonium collapse of melons in Spain (Garcia-Jimenez et al., 1990). The cost per grafted transplant in Spain is 60 pesetas ( $\$ 0.43$ U.S.). With a density of 16,131 plants/ha, costs would approximate $\$ 6936 /$ ha for transplants, which is presently economically prohibitive in the United States. However, these studies demonstrate that Cucurbita sp. possess a high level of resistance to A. cucurbitacearum and perhaps should be evaluated further for control of this vine decline.

Disease reaction to the fungus may be somewhat different under greenhouse than under field conditions, with competing microorganisms and environmental interactions. However, Garcia-Jimenez et al. (1994a) found no useful resistance in 87 muskmelon cultigens planted in Spanish fields with a history of Acremonium collapse. To develop an adequate greenhouse screening of cucurbit germplasm for resistance to A. cucurbitacearum, similar field evaluations are necessary to verify resistance.

\section{Literature Cited}

Abad, P., T. Hack, M. J. Vincente, B.D. Bruton, and J. García-Jiménez. 1997. Vegetative compatibility groups in Acremonium cucurbitacearum, p. 287-289. In: H.-W. Dehne, G. Adam, M. Diekmann, J. Frahm, A. Mauler-Machnik, and P. van Halteren (eds.). Diagnosis and identification of plant pathogens: [Proc. $4^{\text {th }}$ Intl. Symp. European Foundation for Plant Pathol., 9-12 Sept. 1996, Bonn, Germany.] Kluwer Academic Publishers, The Netherlands.

Alfaro-Garcia, A., J. Armengol, B.D. Bruton, W. Gams, J. Garcia-Jimenez, and G. MartinezFerrer. 1996. The taxonomic position of the causal agent of Acremonium collapse. Mycologia 88:804-808.

Armengol, J. 1997. Aspectos patologicos, epidemiologicos y culturales de Acremonium cucurbitacearum Alfaro-Garcia, W. Gams, \& J.
Garcia-Jimenez. PhD Diss., Univ. Politecnica de Valencia, Valencia, Spain.

Armengol, J., E. Sanz, G. Martinez-Ferrer, R. Sales, B.D. Bruton, and J. Garcia-Jimenez. 1998. Host range of Acremonium cucurbitacearum, cause of Acremonium collapse of muskmelon. Plant Pathol. 47:29-35.

Bruton, B.D. 1996a. Una perspectiva historica del decaimiento de cucurbitaceas en los Estados Unidos., p. 30. In: VIII Congress Nac. Soc. Espanola Fitopatol. (Abstr.)

Bruton, B.D. 1996b. Chart of diagnostic characteristics of soil-borne diseases of cantaloupe, p. 10. In: T.A. Zitter, D.L. Hopkins, and C.E. Thomas (eds.). Compendium of cucurbit diseases. Amer. Phytopathol. Soc., St. Paul, Minn.

Bruton, B.D. 1998. Soilborne diseases in Cucurbitaceae: Pathogen virulence and host resistance, p. 143-166. In: J. McCreight (ed.). Cucurbitaceae 98. ASHS Press, Alexandria, Va.

Bruton, B.D., J. Garcia-Jimenez, and J. Armengol. 1999. Analysis of the relationship between temperature and vine declines caused by Acremonium cucurbitacearum and Monosporascus cannonballus. Subtrop. Plant Sci. 51:23-28.

Bruton, B.D., J. García-Jiménez, J. Armengol, and G. Martínez-Ferrer. 1996a. Colapso del melón en las provincias del este y del sur de España, p. 124. In: VIII Congress Nac. Soc. Española Fitopatol. (Abstr.)

Bruton, B.D., J.M. Amador, and M.E. Miller. 1988 Atlas of soil borne diseases of melons. Bul. B1595, Texas Agr. Ext. Serv., College Station.

Bruton, B.D., M.E. Miller, and J. García-Jiménez. 1996b. Comparison of Acremonium sp. from the Lower Rio Grande Valley of Texas with Acremonium sp. from Spain. Phytopathology S86:3. (Abstr.)

Bruton, B.D., R.M. Davis, and T.R. Gordon. 1995. Occurrence of Acremonium sp. and Monosporascus cannonballus in the major cantaloupe and watermelon growing areas of California. Plant Dis. 79:754

Bruton, B.D., V.M. Russo, J. Garcia-Jimenez, and M.E. Miller. 1998. Carbohydrate partitioning, cultural practices, and vine decline diseases of cucurbits, p. 189-200. In: J. McCreight (ed.). Cucurbitaceae '98. ASHS Press, Alexandria, Va.

Cluck, T., C. Bruton, C. Biles, C. Heard, J. Armengol, and J. Garcia-Jimenez. 1997. Effect of carbohydrates on chlamydospore production of Acremonium cucurbitacearum. Proc. Okla.
Acad. Sci. 77:136. (Abstr.)

García-Jimenez, J., J. Armengol, and G. MartínezFerrer. 1994a. Resistencia y comportamiento en campo de diversos cultivares de melón crecidos en suelo infestado naturalmente con Acremonium sp. Inv. Agr. Prod. Prot. Veg. Fuera seri. 2:263274.

García-Jiménez, J., M. García-Morato, M.T. Velázquez, and A. Alfaro. 1990. Ensayos preliminares de control de la muerte subita del melón mediante la utilizacion de portainjertos resistentes. Bol. San. Veg. Plagas 16:709-715.

García-Jiménez, J., T. Velázquez, C. Jorda, and A. Alfaro-García. 1994b. Acremonium sp., causal agent of muskmelon collapse in Spain. Plant Dis. 78:416-419.

Gubler, W.D. 1982. Epidemiology and control of Cephalosporium root and hypocotyl rot of melon in California. PhD Diss., Univ. of California, Davis.

Gubler, W.D. 1996. Acremonium hypocotyl rot, p. 9. In: T.A. Zitter, D.L. Hopkins, and C.E. Thomas (eds.). Compendium of cucurbit diseases. Amer. Phytopathol. Soc., St. Paul, Minn.

Gwynne, B.J., R.M. Davis, and T.R. Gordon. 1997. Occurrence and pathogenicity of fungi associated with melon vine decline in California. Phytopathology 87:S37. (Abstr.)

Hartz, T.K., W.W. Carter, and B.D. Bruton. 1987 Failure of fumigation and solarization to control Macrophomina phaseolina and subsequent muskmelon vine decline. Crop Protect. 6:261264.

Hopkins, D.L. and G.W. Elmstrom. 1984. Fusarium wilt in watermelon cultivars grown in a 4-year monoculture. Plant Dis. 68:129-131.

Mertely, J.C., R.D. Martyn, M.E. Miller, and B.D. Bruton. 1993. An expanded host range for the muskmelon pathogen Monosporascus cannonballus. Plant Dis. 77:667-673.

Miller, M.E. (ed.). 1990. Melon production systems in South Texas. Annu. Res. Rpt., Texas Agr. Expt. Sta., Weslaco.

Miller, M.E., R.D. Martyn, B.R. Lovic, and B.D. Bruton. 1995. An overview of vine decline diseases of melons, p. 31-35. In: G. Lester and J. Dunlap (eds.). Cucurbitaceae '94. Gateway Printing, Edinburg, Texas.

Vincente, M.J.,P. Abad, T. Hack, B.D. Bruton, and J. García-Jiménez. 1996. Compatibilidad vegetativa entre aislados Españoles y Americanos de Acremonium cucurbitacearum, p. 138. In: VIII Cong. Nac. Soc. Española Fitopatol. (Abstr.) 